\title{
A Study on Assessment of Anthropometric Measurements and Dietary Intakes among Adult Males in Nagarjuna University, Guntur District, Andhra Pradesh, India
}

\author{
Sudha Rani .. ${ }^{1}$, V. Chinnari Harika ${ }^{2}$ \\ Department of Foods and Nutritional Sciences, Acharya Nagarjuna University, Nagarjuna Nagar - 522510
}

\begin{abstract}
The objective of the present study is to assess nutritional status of adults, for this purpose the present study has been conducted to assess the nutritional status of males. The group comprised of 60 males aged 20-24 years, studying in Nagarjuna University. Relevant data on anthropometric measurements and BMI classification percentages was collected. Anthropometric data on height and weight of adult males were measured. One commonly used indicator i.e., Body mass index (BMI; kg/m2), was used to evaluate the nutritional status of the subjects. The study reveals that there were lower consumption in several macro and micro nutrients intake compared to Recommended Dietary Allowances (RDA) of India, which may be reflected on their nutritional status.
\end{abstract}

Keywords: Adults, Anthropometric measurements, BMI and Nutrient intakes.

\section{Introduction}

Anthropometry is considered to be an important tool for assessing nutritional status of individuals or of the community. Hence, measurements like stature, sitting height, weight and indices based on these measurements developed by different scholars have been extensively used to define the extent of malnutrition. Body weight to height squared can be a good parameter to grade chronic energy deficiency (CED) in adults (Naidu et al., 1991). There are many studies based on this aspect (for example Ferro-Luzzi et al.,1991; Khongsdier, 2001). Inadequacies in nutritional intake or under-nutrition can be considered as a major source of many adverse effects on the growth and health of individuals (Gordon et al., 1968).

Anthropometry is of substantial interest to the public health professionals, dieticians, scientists and policy makers. It has long been well established that the use of anthropometry is an efficient indicator of nutritional and health status of adults (WHO, 1995) Nutrition research in anthropometric assessment of nutritional status in anthropology and biological subjects including health and medicine is therefore, gaining importance in the present days. Low Body Mass Index (BMI) and high levels of under nutrition (based on BMI) are the major public health problems especially among rural underprivileged adults of developing Countries.

Nutrition plays an important role in the health and development of an individual (UNICEF, 2010). The adequate nutritional needs of an individual ensure tissue renewal, maintaining a good physical and mental health, but also reduce the risk of non communicable diseases related to food (C.D.U, 2009). Dietary intakes not meeting the needs of the body are the cause of malnutrition. Malnutrition is a health problem caused by excessive food intake (over nutrition), inadequate or imbalanced diet does not contain all the nutrients needed for good nutritional status (under nutrition) (FAO, 2003).

\section{Materials and Methods}

The present study was carried out in Nagarjuna University, Guntur District, Andhra Pradesh, India. The survey work was done during January to April, 2014. The study sample is based on basic anthropometric data collected on adult males aged 20-22 years by the Anthropological Survey of India (Basu et al., 1994). The data for the present study have been collected from 60 male students, in the age group of 20-24 years belonging to university students from various departments.

\section{Height (cm)}

The height of the adults was measured using the method described by Jellifee (1966). The subject was made to stand on an even floor with back touching the wall, the feet parallel with heels, buttocks and shoulders and back of head touching upright. The head was made erect with the lower border of the orbit measures and the arms hanging at the side in a natural manner.

\section{Weight (Kg)}

The weight was measured by using procedure described by Jellifee (1966) using bathroom scales. The balance was placed on an even floor. The subject with light clothes (0.4$0.6 \mathrm{~kg}$ ) were requested to stand on the center of the balance (foot rest plate) with head erect. The weight was recorded avoiding parallax error. The weight was expressed in kilograms. To minimize the error, the same balance was used throughout the study and the balance was checked periodically with standard weight adjusting to read zero in the resting position.

\section{Body Mass Index (BMI)}

BMI is also known as Quetlet index. BMI was calculated using the formula: $\mathrm{BMI}=$ Weight $(\mathrm{Kg}) /$ height $\left(\mathrm{m}^{2}\right)$. The size and weight were used to determine the body mass index (BMI) according to the formula, weight $(\mathrm{Kg})$ divided by the 


\section{International Journal of Science and Research (IJSR) \\ ISSN (Online): 2319-7064}

Index Copernicus Value (2013): 6.14 | Impact Factor (2014): 5.611

square of height $(\mathrm{m} 2)(\mathrm{Kg} / \mathrm{m} 2)$. BMI categories were selected in accordance with WHO recommendations.

\section{Calculation of Body Mass Index (BMI):}

\section{BMI was calculated using the equation: Weight $(\mathrm{kg})$}

\section{Height $\left(\mathrm{m}^{2}\right)$}

Data Collection: Diet survey was carried out by weighing method (Rao et al.,1986).Quantitative dietary assessment was done through actual weighing of raw food item. The average dietary intake of food per item was calculated and was compared with the RDA (Recommended Dietary Allowances) of India using the values as per 'Nutritive Value of Indian Food' (Gopalan et al., 2006).

\section{Results and Discussion}

Table 1: Anthropometric Classifications for Adults

\begin{tabular}{|c|c|c|c|}
\hline S. No & Grades & BMI levels & Males $(N=60)$ \\
\hline 1. & CED Grade III: BMI & $<16.0$ & $1(1.6)$ \\
\hline 2. & CED Grade II: BMI & $16.0-16.9$ & $2(3.3)$ \\
\hline 3. & CED Grade I: BMI & $17.0-18.4$ & $7(11.6)$ \\
\hline 4. & Normal: BMI & $18.5-24.9$ & $36(60.0)$ \\
\hline 5. & Overweight: BMI & $25.0-29.9$ & $14(23.3)$ \\
\hline 6. & Obese, Class I & $30.0-34.9$ & - \\
\hline 7. & Obese, Class II & $35.0-39.9$ & - \\
\hline 8. & $\geq 40$ & Obese, Class III & - \\
\hline
\end{tabular}

World Health Organization, (WHO, 1995).

Table 1 reveals percent of subjects at different grades of BMI in male adults about 1.6 per cent of subjects were in $<16$ BMI (Chronic Energy deficiency grade -III). 3.3 per cent were between 16.-16.9 BMI (Chronic Energy deficiency grade -II)11.6 per cent of subjects were in 17.018.5 BMI (Chronic Energy deficiency grade- I), 60.0 per cent were in normal BMI level and 23.3 per cent were in over weight level.

Table 2: Mean Anthropometric Measurements of subjects

\begin{tabular}{|c|c|c|c|}
\hline S.No & Measurements & $\begin{array}{c}\text { Mean } \pm \text { SD } \\
\text { (Range)Males }\end{array}$ & $\begin{array}{c}\text { ICMR } \\
\text { Standards }\end{array}$ \\
\hline 1. & Height $(\mathrm{cm})$ & $\begin{array}{c}167.9 \pm 68.72 \\
(152-189)\end{array}$ & 163.0 \\
\hline $\mathbf{2 .}$ & Weight $(\mathrm{kg})$ & $\begin{array}{c}58.65 \pm 20.5 \\
(44-72)\end{array}$ & 51.3 \\
\hline $\mathbf{3 .}$ & BMI & $\begin{array}{c}22 \pm 17.6 \\
(17.3-28.1)\end{array}$ & 23.75 \\
\hline 4. & $\begin{array}{c}\text { Arm circumference } \\
(\mathrm{cm})\end{array}$ & $\begin{array}{c}26.98 \pm 19.26 \\
(18-34)\end{array}$ & 26.9 \\
\hline
\end{tabular}

Table 2 Shows the mean Height of the subjects were $167.9 \pm$ $68.72 \mathrm{~cm}$ and the ranges are $152-189 \mathrm{~cm}$. The mean heights were compared to ICMR (Indian Counsel of Medical Research) standards. The Heights of the male subjects were slightly higher than the standards due to genetic factor and physical activity. The mean values of weight of the males were $58.65 \pm 20.5 \mathrm{~cm}$ and the ranges were $44-72 \mathrm{~cm}$. Body mass index of the male subjects were $22 \pm 17.6$ and the ranges were 17.3-28.1. Body mass index of the male subjects were normal when compared to the standard values. Arm circumferences of male adults were $26.98 \pm 19.26 \mathrm{~cm}$ and the ranges were $18-34 \mathrm{~cm}$.
Nutritional anthropometry can be defined as a measurement of the physical dimensions and gross composition of the human body as a means of assessing nutritional status. Quetlet's Index, or BMI, is widely used as a measure of fatness, or the nutritional status of populations in both developed and developing countries (Khongsdier, 2001). Recent studies have, however, questioned the validity of BMI as an indicator of fatness (Frankenfield et al., 2001; Kyle et al., 2003). BMI is the most established anthropometric indicator used for assessment of adult nutritional status (Shetty et al.,1994). BMI is generally considered a good indicator of not only the nutritional status but also the socio-economic condition of a population, especially adult populations of developing countries (Adak et al.,2006,Lee RD, Nieman,2007, Khongsdier,2002).

Table 3: Mean Nutrient intake of Adults

\begin{tabular}{|c|c|c|c|}
\hline S.no & Nutrients & Male & RDA \\
\hline 1. & Energy (k.cal) & $\begin{array}{c}2191.81 \pm 22.28 \\
(1685-2729)\end{array}$ & 2875 \\
\hline 2. & Protein (gms) & $\begin{array}{c}50.10 \pm 2.96 \\
(40.6-59.09)\end{array}$ & 60 \\
\hline 3. & Iron (mg) & $\begin{array}{c}10.52 \pm 2.13 \\
(7.26-15.42)\end{array}$ & 28 \\
\hline 4. & Calcium (mg) & $\begin{array}{c}906.94 \pm 113.65 \\
(729.4-1126.34)\end{array}$ & 400 \\
\hline 5. & Vitamin C (mg) & $\begin{array}{c}73.0 \pm 11.40 \\
(46.76-99.32)\end{array}$ & 40 \\
\hline 6. & Folic acid ( $\mu$ g) & $\begin{array}{c}119.38 \pm 22.3 \\
(88.78-129.5)\end{array}$ & 100 \\
\hline
\end{tabular}

Table 3 shows the mean Nutrient intake of males, the mean nutrient (macro and micro) intake per consumption unit per day among male adults of Central India. The mean calories intakes among males were $(2191.81 \pm 22.28 \mathrm{kcal})$. The mean protein intakes among males were $(50.10 \pm 2.96 \mathrm{gms})$. The mean intake of calories and protein were lower when compared to Recommended Dietary Allowances (RDA) of India. Calcium and iron were lower than the standards. Folic acid is slightly higher than the standards. A dietary approach made from a food survey presented foods commonly consumed by population recruited indicated very monotonous eating habit combined with imbalanced diets. The frequency of consumption of the identified foods showed that carbohydrate foods and fat were the most abundant and frequently consumed. While consumption of fruits, vegetable and protein foods were low. The same observations were obtained by Kana Sop et al, (2010) in Cameroonians students of University of Douala. The study also indicates a need for effective implementation of nutrition and Balanced diets and other information like dietary intake, morbidity and health studies (Dipak et al., 2006). The low consumption of fruits and vegetables has also been observed in this population. Fruits and vegetables contain several types of vitamins and minerals essential to the body. Hence lack of vitamins and minerals is the cause of many health problems.

\section{Conclusion}

The present study was on nutritional status of male adults and the study also indicates a need for effective implementation of nutrition and Balanced diets among male adults. Other information like Dietary intake and

\section{Volume 4 Issue 12, December 2015}




\section{International Journal of Science and Research (IJSR) \\ ISSN (Online): 2319-7064 \\ Index Copernicus Value (2013): 6.14 | Impact Factor (2014): 5.611}

anthropometric measurements. BMI Grades also one of the indicator of nutritional status. Malnutrition is a health problem caused by excessive food intake (over nutrition), inadequate or imbalanced diet does not contain all the nutrients needed for good nutritional status.

\section{Acknowledgements}

The author express their sincere thanks to Head of the Department of Foods and Nutritional Sciences for providing the required facilities and giving valuable suggestions.

\section{References}

[1] Adak D, Gautam RK, Bharat S, Gharami AK, Pal M, Bharati P. Body Mass Index and chronic energy deficiency of adult males of Central Indian Populations. Hum Biol 2006; 78 (2): 161-78.

[2] Basu A, Mukherjee DP, Dutta PC, BoseDK, Basu MP, Ghosh GC, Kumar GD \& Huq F (1994). All India Anthropometric Survey: North Zone Basic Anthropometric Data, Vol. I: Madhya Pradesh. Calcutta, Anthropological Survey of India.

[3] C.D.U (Comite de Direction de l'Unité) (2009). Besoins nutritionnels et' apport alimentaire de l'adulte. Evaluation de l'état nutritionnel. Ed. Vernazobres. France, pp1-5.

[4] Diehl K., Thiel A., Zipfel S., Mayer J., Litaker D.G., Schneider S. (2012). How Healthy is the Behavior of Young Athletes? A Systematic Literature Review and Meta-Analyses. J. Sports Sci. Med. 2012 Jun 1; 11(2):201-220.

[5] Dipak K Adak, Rajesh K Gautam \& Ajay K Gharami (2006). Assessment of Nutritional Status through Body Mass Index among Adult Males of 7 Tribal Populations of Maharashtra,India. Mal J Nutr 12(1): 23-31.

[6] FAO (2003). Ciblage et amélioration de la nutrition: Moyens d'améliorer le statut nutritionnel. Ed. Press de l'université d'oxford. Rome, 107p.

[7] Ferro-Luzzi A, Sette S, Franklin M \& James WPT (1991). A Simplified approach of assessing adult chronic energy deficiency. Eur J Clin Nu tr 46:173-186.

[8] Frankenfield DC, Rowe WA, Cooney RN,Smith JS \& Becker D (2001). Limits of body mass index to detect obesity and predict body composition.Nutrition 17: 2630 .

[9] Gopalan, C., Ramsastri, B.V. and Balasubramanium,(2006). S.C.:Nutritive value of Indian Food. Indian Institute of Nutrition, Hyderabad.

[10] Gordon JE, Ascoli W, Mata LJ, Guzman MA \& Scrimshaw NS (1968).Nutrition and infection field study in Guatemalan villages 1959-1964, Acute diarheal disease and nutrition disorder in general disease incidence. Archives Environ Hlth 16: 424-437.

[11] James WPT, Ferro-Luzzi A \& Waterlow JC (1988). Definition of chronic energy deficiency in adults. Eur $J$ Clin Nutr 42:969-981.

[12] Jelliffe, D.B.: The Assessment of the Nutritional Status of the Community. WHO Monograph Series No. 56, WHO, Geneva (1966).

[13] Kana Sop SM, Gouado I, Tetanye E and Amvam Zollo PH (2010). Nutritional status food habits and energy profile of young adult Cameroonian University students. Afr. J. Foo. Sci. 4 (12): 748-753.

[14] Khongsdier R (2001). Body mass index of adult males in 12 populations of Northeast India. Annals of Human Biology 28:374-383.

[15] Khongsdier R. Body mass index and morbidity in adult males of the War Khasi in Northeast India. Eur J Clin Nutr 2002;56: 484-9.

[16] Kyle UG, Schutz Y, Dupertuis YM \& Pichard C (2003). Body composition interpretation: contribution of the fat free mass index and the body fat mass index. Nutrition 19: 597-604.

[17] Lee RD, Nieman DC. Nutritional Assessment. New York: McGraw Hill, 2007.

[18] Naidu AN, Neela J \& Rao NP (1991).Maternal body mass index and birthweight. Nutrition News, National Nutrition,Hyderabad, India (1986).

[19] Rao, N.F., Camnath, T. and Sastry, J.G. [1986] Diet and nutrition in urban areas. Proc. Nutr. Soc., 32:91-99.

[20] Shetty PS, Soares MJ, James WPT. Body mass index: Itsrelationship to basal metabolic rates and energy requirements. Eur J Clin Nutr 1994; 48 (suppl. 3): S2838.

[21]UNICEF (2010). La malnutrition responsable de la moitié des décès. Vernazobres. France, pp1-5.

[22] World Health Organization (WHO). Physical Status: the Use and Interpretation of Anthropometry. Technical Report Series no. 854. Geneva: World Health Organization, 1995.

[23] www.unicef.fr/la-malnutrition-responsable-de-la-moitiedes-decesd'enfants. 